\title{
DANCE AND COSTUME. FROM THE TRADITION TO PERFORMANCE
}

\section{Filippou Filippos, Harahoussou Ivonni, Kabitsis Christos, Koleta Maria}

According to dance sociologists and anthropologist, folk dance is an aspect of human behaviour, a non-verbal system of communication in which society itself is reflected. Dance, apart from motion, also covers the areas surrounding it: the environment where it occurs and develops, the relationships between the dancers themselves and between the dancers and spectators, the objects used during the performance and even the dancers' costumes.

But what was the traditional Greek costume like? The common understanding (Vrelli-Zaxou 1994) is that traditional costume is the costume, which on the one hand defines the identity of an agricultural society and on the other expresses the relationship between an individual and the society. Giselis (1974) writes that the costume is a symbol of the group and not of its wearer's personality, which under pressure may be forced to conform to the communal spirit. It is never easy to distinguish oneself from the community with a costume (Vrelli-Zaxou 1994), since the society itself activates the mechanism of social control and sanctions forcing a possible future innovator to return to the order. The main characteristic of folk costume is that it is generally accepted by the majority (Vrelli-Zaxou 1994). We cannot overlook the fact that the word 'costume', which is a foreign word for the Greek, is derived from the English word 'costume' and its doublet 'custom', which in their turn are derivations of Latin consuetudo 'habit'.

All the above is derived from the fact that every place has its own costume. The common distinction by several authors (e.g. Roubis $1995)$ between the costumes of the inhabitants of mountainous regions and those living on the plains, and also between the costumes of the islanders and the inhabitants of mainland, is no longer valid, as research has proved that a century ago villages distinguished themselves from others with a characteristic costume (Hatzimichali 1925). 
Photo 1. A couple in Greek traditional costume. Photo $C D$ of the congress Dance as Intagible Heritage, in Corfo, 2002, Oct. 30 - Nov. 3.

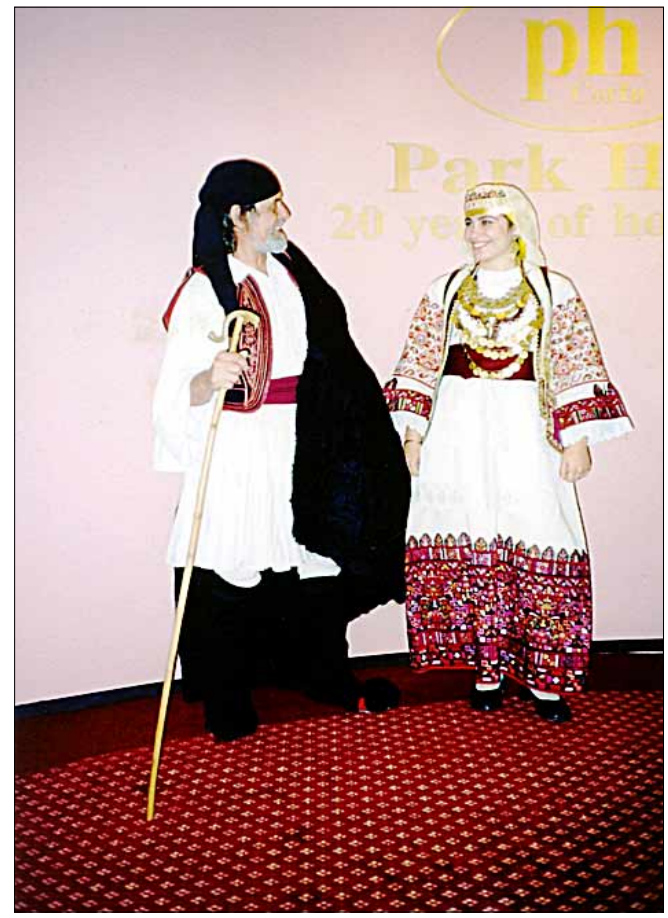

In traditional society a costume may have had various functions. One of its functions was to reflect the alteration of the work days and the holidays, the days of leisure. They differ morphologically as far as the quality and decoration is concerned (Kyriakidou-Nestoros 1989). The costume for everyday usage is very practical in its dark colours and without any embroidery and decorative elements. Festive garments, on the other hand, are traditionally rich in colours and ornamentation. The festive costume is widely used in formal dancing and at festivals all over Greece. There are of course some regions where a special costume is worn for different occasions: in the village of Nestani, Arkadias (Vrelli-Zaxou 1994) men wear the tsipianitiko shirt and women wear asprofoustano, a certain kind of white dress, in Sirako, Iperos (Dimas 1993) certain rustic shoes are worn on festive occasions, mainly during dancing, and to facilitate dancing the shoes are made without nails. We should mention here that the local costumes assumed their final appearance (Papantoniou 
1985) through gradual evolution and changes by the late 19th century, shortly before being abandoned in favour of the second and more dynamic invasion of western fashion introduced by Queen Olga. The final abandoning of the traditional costume and its total urbanisation took place during the Second World War.

Another function of the costume in the traditional society was to indicate its wearer's social status (Raftis 1992), especially in communities of intensive social mobility. In such communities a costume may have helped to differentiate between members of the community, and were not forbidden in dancing.

Furthermore, a costume may have been a token of its wearer's social age. Women's costumes, in particular, differed more in details. Women's costumes changed a lot during their life. The clothes worn in the early age are rich in embroidery and ornamentation, and become more conservative with the advancement of age. Each age group wears a different kind of costume; the clothes also help to distinguish between unmarried and married women, between the newly married women and the married women, women with children and widows. All age groups took part in public dancing, though in some communities the priority was given to single people. The older the women get, the less they dance, and if they did then only in exceptional occasions. Men, however, never stopped dancing.

At the beginning of the 1970s many cultural associations were established as a result of a barely existing folklore movement in Greece. Today the traditional Greek dance is revived and promoted by dance associations who perform in Greece and abroad all year round. Here we should define the word 'performance', 'perform'. According to the Tegopoulos-Fitrakis 1993 Greek-English bilingual dictionary 'performance' is "rendering of the abstract into the tangible" and 'to perform' stands for "describe, represent". 'Describe', in other words, means "to provide the audience all the conditions and elements that would carry them back to the time, the place and the climate, which dominated at the time of the real event."

Several researchers have pointed to the costume's role in the success or failure of a dancing performance. Shay (1999) argues that the choice of dances of some dance groups depend on whether they 
do or do not have traditional costumes and the quality of costumes. According to Serbezis (1999) the quality of a performance depends largely on the use of traditional costume or the manufacture quality of those that are bought. Goulimaris, Serbezis and Theodorakis (1999) agree that a costume is a major factor in determining the quality of traditional dance performances. According to the above, a costume is once of the main factors in the formation of dancing performance.

The main assumption of this study is that the use of traditional costume during a performance should convey the audience the atmosphere of the event, the message of the dance, the values and facets of traditional society. The article aims to study the use of traditional costume during performance by dance groups.

\section{METHODOLOGY}

The study is based on the analysis of 75 dance performances, recorded on video during May 2000 - May 2001. 310 dance groups all over Greece participated in the performances. 140 of the total groups represent one ethnic group, and the remaining 170 groups represent more than one ethnic group or are cultural organisations (Dora Stratou Theatre, The Lyceum Club of Greek Women, the Municipalities, etc.) The method of quality analysis was used.

\section{Traditional costume in performance practice}

We may categorise dance associations by ethnic representation, and divide them in two major categories. Firstly, the associations that represent exclusively one cultural group, hereinafter referred to as 'ethnic', and secondly, the associations that represent more than one cultural group. Dance associations may also be categorised by the program's place of origin into three major groups: 1) the associations performing exclusively dances of the cultural group they represent, the sc. 'ethnic associations'; 2) the dance associations representing different ethnic groups, such as Dora Stratou Theatre, the local Lyceum Club of Greek Women, or the Municipalities; and 3 ) the ethnic associations performing both the dances of a certain cultural group and dances from all over Greece. 


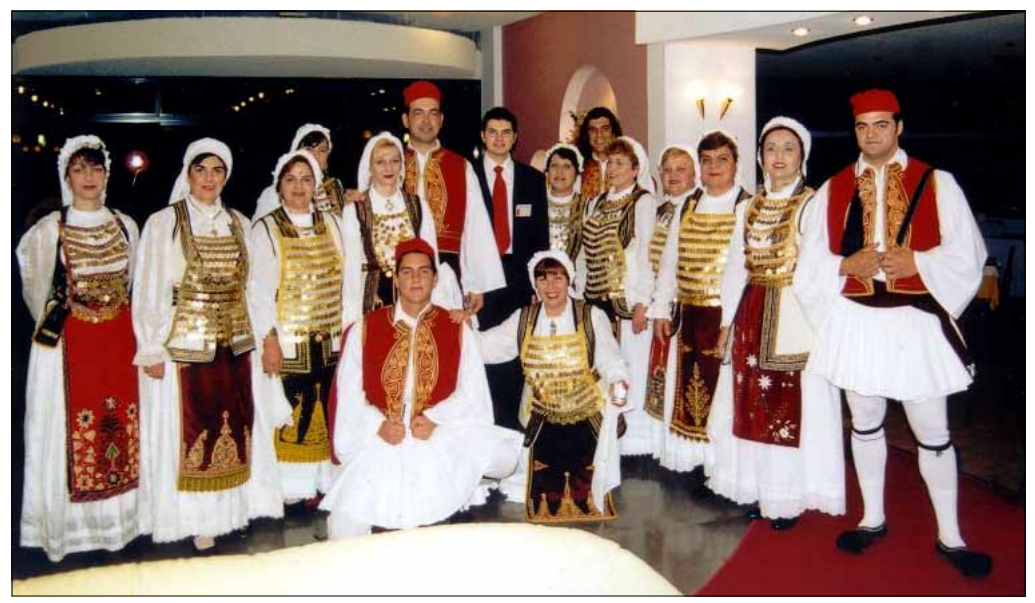

Photo 2. A professional Greek folk dancing group. Photo CD of the congress Dance as Intagible Heritage, in Corfo, 2002, Oct. 30 - Nov. 3.

Based on the video analysis we could conclude the following:

(a) Ethnic dance associations perform the dances of the ethnic group they represent, always wearing corresponding costumes.

(b) The dance associations performing dances from all over Greece can be further divided in two: firstly, the associations performing dances of a specific area, wearing the corresponding costume (such associations are Dora Stratou Theatre, the Lyceum Club of Greek Women of Athens and Thessaloniki, the Peloponnesian Folklore Foundation in Nafplion. And secondly, all the other associations performing the dances of one area or one ethnic group, wearing random costumes. The latter group is considerably larger. The attempts of some dance associations to perform dances of a certain region with costumes of its neighbouring regions or with costumes imitating the costume of the region do not change the result.

The preliminary conclusions reveal that most of the dance associations do not regard the costume as a defining element of the local and ethnic identity of the group, but is used as a decorative element of the performance. Obviously this does not bother the spectators 
of the performance: a research indicates that only $36 \%$ of spectators were not bothered when dances of a certain region were performed in costumes of an altogether different region (Filippou 1999; 2002). Managers of dance associations often refer to this number to justify their reluctance to procure authentic costumes of all the regions or ethnic groups, whose dances they perform, with poor financial means of the associations.

According to the above research $71 \%$ of the spectators disagree with the managers of dance associations and disapprove that the dancer's costumes are neglected or ill-matching, 58\% disapprove the dressing of female dancers in men's costumes due to the lack of male dancers, and finally, $26 \%$ have a problem with the incomplete costumes of the dancers.

Unfortunately, all the above conclusions are drawn from video analysis. Dance teachers are practicing some sort of weird transvestism with the pupil's parents' silent consent (Pop 1984, 1993) and dress women in men's costumes when performing traditional men's dances, and also other dances. This phenomenon was started a few years ago by a dance association from Pontos (Raftis 1992), and it spread very quickly. Our study reveals that 143 associations, mainly village dance groups, (i.e. 46,1\%) of the total of 310 associations had women dressed in men's costumes.

The shirt, the apron and the belt have a specific meaning in the traditional women's costume (Papantoniou 1975; Pop 1981) and were worn in a certain way. As we have already mentioned, most female dancers do not wear these accessories correctly, and the costume, as a whole, appears disorderly and neglected. The very fact may suggest that the dancers and association managers pay little attention to the costume. One reason is certainly that most dance associations do not have a professional designer, also the dance teachers are not familiar with the traditional costume of the ethnic group they represent or with the traditional Hellenic costumes in general (Filippou 2002). This ignorance and also the lack of finances may be the reason why the costumes, mainly women's clothes and headbands, have been simplified and are incomplete. This has resulted in stylised costumes, which have very little in common with the authentic historical costumes. 
Finally, the analysis of video performances do not reveal the time of origin of the costumes, or the social class or group the costumes represent, or at which time the dance was performed. This is because the performing dancers are often clad in festive or bridal dress, even while performing ritual dances, representing cattle and agriculture.

\section{CONCLUSION}

The spectators following a dance performance representing a specific ethnic group do not always wear traditional costumes. For most dance associations, costumes have a decorative function, and are used to guarantee a good show.

\section{References}

Dimas, S. I. 1993. I xoreftiki paradosi tis Ipirou. Athina.

Filippou, F. 2002. Syntelestes parastaseon paradosiakou xorou sti sihroni Elliniki paragmatikotita: I periptosi tou N. Imathias. Manuscript: doctoral dissertation. Democritus University of Thrace; Komotini.

Gizelis, Gregory 1974. I ritoriki tou endimatos. Athina.

Goulimaris, D. \& Serbezis, V. \& Theodorakis N. 1999. I dierevnisi tis adilamvanomenis piotitas ton ipiresion stis parastasis paradosiakou xorou stin Ellada. Athlitiki apodosi ke igia, Vol. 4, pp. 359-369.

Hatzimihali, Angelike 1925. Elliniki laiki tehni: Skyros. Athina.

Kyriakidou-Nestoros, Alke 1989. Laogrfika Melethmata 1. Athena: Hetaireia Hellenikou Logotechnikou kai Historikou Archeiou.

Papantoniou, Ioanna 1975. Symvoli sti meleti tis ginekias ellinikis paradosiakis Foresias. Nafplion: Peloponnisiako Laografiko Idrima.

Papantoniou, Ioanna 1985. I elliniki ginekia foresia ke to kosmima allote ke tora. Naflio: Peloponnisiako Laografiko Idrima.

Pop, Denise 1981. Costume traditionel et pratique religieuse en Romanie. Paris: E.H.E.S.S.

Pop, Denise 1984. Evolution d' un système vestimentaire: L' importance du choix dans les sociétés paysans et rurales de Roumanie. Paris: E.H.E.S.S.

Pop, Denise 1993. Ethnologie et sémiologie du vêtement. Paris: E.H.E.S.S.

Raftis, Alkis 1992. Xoros, politismos ke kinonia. Athina: Dora Stratou.

Roubis, A. G. 1995. Elliniki xoroi. Athina: TO OIKONOMIKO.

Serbezis, Vasileios 1999. Paradosi - parastasi epi skinis: Laiki dimiourgia i eponimi diaidkasia? Likio Ellinidon Dramas. 
Shay, Anthony 1999. Parallel Traditions: State Folk Dance Ensembles and Folk Dance in the "field". Dance Research Journal, Vol. 31, No. 1, pp. $29-56$.

Tegopoulos-Fitrakis 1993. Helliniko Leksiko. Athina: Armonia.

Vrelli-Zaxou M. 1994. Dance and costume: Tradition and representation. Dance and Society. Pnevmatiko: Kentro Konitsas, pp. 97-107. 